\title{
How do family relations influence interethnic partner choices? The role of cohesion, affection and diversity in native and migrant families
}

\author{
Wie beeinflussen Familienbeziehungen die interethnische Partnerwahl? \\ Die Rolle kohäsiver, affektiver und heterogener Beziehungen in \\ einheimischen und eingewanderten Familien
}

\begin{abstract}
:
Despite the well-documented effect of parental attitudes and their socioeconomic status on interethnic partnerships, little is known about how family relations are associated with interethnic partner choices. The present study investigates whether cohesive and affective family ties as well as the family structure is connected to interethnic partnerships. Based on data from wave five of the German Family Panel (pairfam), I estimate logistic regression models for natives and migrants separately. Results indicate that for natives, cohesive and affective relations are not connected to interethnic partnerships. For migrants, cohesive relations have a detrimental effect on being in an interethnic partnership. Overall, these findings suggest that family processes may help to understand why some migrant groups are more likely to be in an interethnic union than others.
\end{abstract}

Keywords: interethnic partner choice, family relation, migrant

\section{Zusammenfassung:}

Obwohl der Zusammenhang von Charakteristika der Eltern und ihren Einstellungen gegenüber interethnischen Partnerschaften häufig erforscht wurde, ist die Rolle der Familienbeziehungen unklar. Die vorliegende Studie untersucht den Effekt von kohäsiven, affektiven und diversen Familienbeziehungen auf interethnische Partnerschaften. Basierend auf den Daten der fünften Welle des Deutschen Familienpanels (pairfam) schätze ich logistische Regressionsmodelle für Einheimische und Migranten. Die Ergebnisse zeigen, dass für Einheimische kohäsive und affektive Beziehungen die Partnerwahl nicht betreffen. Bei Migranten wirken hingegen kohäsive Beziehungen negativ auf die interethnische Partnerwahl. Diese Ergebnisse deuten darauf hin, dass Familienbeziehungen wichtig sind um Unterschiede zwischen Migranten in interethnischen Partnerschaften zu verstehen.

Schlagwörter: interethnische Partnerschaft, Familienbeziehungen, Migranten

* A previous version of this paper was submitted as a term paper in pursuit of a Master's degree. 


\section{Introduction}

Marriage is the most intimate form of a social relationship (Kalmijn 1998; Song 2009) and thus, marriages between members of different ethnic and cultural groups - i.e., interethnic marriages - are often associated with close social interactions across these groups (Qian/Lichter 2001; Lichter et al. 2007; Song 2009). Interethnic marriage links the families, friends, and lives of natives and migrants and is therefore considered to indicate natives' and migrants' mutual acceptance as social equals (Lichter et al. 2007). Gordon (1964) suggests that intermarriage is the final step in the social integration process of immigrant populations. In order to understand how and why members of different ethnic groups intermarry, Kalmijn (1998) proposes that the interethnic partner choice depends next to preferences for specific characteristics of the future spouse and the possibility to meet potential partners on third parties such as the family. However, our understanding of how the relationship to one's family affects interethnic partner choice is limited. This raises the following question: to what extent and how can cohesive, affective and diverse family ties explain interethnic partner choices?

Many studies confirm that the family plays a relevant role in interethnic partner choices (e.g., Kalmijn/van Tubergen 2006; van Zantvliet et al. 2014; Carol 2015). Attitudes toward interethnic partnerships are formed in the family context (Huijnk/Liefbroer 2012; Carol 2013a; Huijnk et al. 2013) and transmitted from one generation to the next. For instance, Carol (2013b) studies parental and children's attitudes toward interethnic partnerships simultaneously and finds that children's attitudes toward interethnic partnerships are negative if parents' preferences for coethnic partnerships are strong. Huijnk and colleagues highlight the role of family relations in the formation of attitudes towards interethnic partnerships (Huijnk et al. 2010; Huijnk/Liefbroer 2012; Huijnk et al. 2013). Members of close and cohesive families possess negative attitudes towards members of other ethnic groups as close kin by marriage. In turn, warm and affective family relations lead to more tolerance for interethnic partnerships. Despite the vast amount of research on the link between parental characteristics and children's interethnic partnerships, Steinbach/Hank (2016) point out that the effect of family relations on partner choice remains understudied.

The present study takes up the perspective that family relations influence and transmit attitudes toward interethnic partnerships and takes it further by studying the effect of family functioning on the actual interethnic partner choice. I set out the following research question: Are cohesive, affective, and diverse family relations linked to the interethnic partner choice? I am interested in whether the relationship to parents and siblings is connected to interethnic partner choices. To answer this question, I use data from the German Family Panel (pairfam) and study the effect of cohesive, affective, and diverse relations to parents and siblings on interethnic partner choice in Germany. Given the wide range of migrants from different countries who differ in their family relations from native Germans, I study the influence of family relations on interethnic partner choices for native Germans and migrants separately.

The German immigration history is characterized by a first inflow of migrants from Italy, Spain, Greece, Turkey and former Yugoslavia. They were recruited as guest workers in the mid-1960s to offset labor shortages due to economic growth after the Second 
World War. In the early 1990s, another migration wave began when ethnic Germans (Aussiedler) from the former Soviet Union and refugees from the Yugoslav Wars came to Germany. Today, one in five persons in Germany has a migration background and the largest migrant groups come from Turkey, Poland, Russia, and Italy (Statistisches Bundesamt 2017).

\section{Theoretical framework}

Why are some people more likely to intermarry than others? Individual preferences, opportunity structure, and third parties are prominent factors in answering this question (Kalmijn 1998). The partner choice is dominated by a preference for homophily which means that individuals prefer to marry someone who is similar to themselves. Individual preferences refer not only to specific socioeconomic preferences (e.g., educational background) but as well to cultural resources such as shared attitudes and values. The interethnic partner choice also depends upon the meeting opportunities of natives and migrants. The size, geographical distribution, and sex ratio of the own cultural group determines the pool of potential coethnic partners and thus, the chance to find a coethnic or interethnic partner. For example, members of large ethnic groups have a larger pool of potential coethnic partners than members of small ethnic groups. Thus, members from large ethnic groups are more often married to each other while members of small groups are more often married to members from other groups (Schroedter 2013). Moreover, interethnic partner choices are dependent upon third parties. Third parties are situated outside the couple and have an effect on the individual's partner choice. The family, church, or state are prominent third parties; they prefer in-group to out-group members in order to facilitate the transmission of cultural values and norms (Dribe/Lundh 2011) and to ensure solidarity between members (Huijnk et al. 2013).

Looking more closely on the effect of families on interethnic partner choices, the transmission of cultural values and norms (Dribe/Lundh 2011; Munniksma et al. 2012; Carol 2013a) and family solidarity (Huijnk et al. 2013) may be endangered if members of other cultural groups are part of the family. For example, culture-specific traits may not be transmitted to the next generation and family solidarity may be endangered if two persons with different origin marry. Family relations are more intense (Nauck/Suckow 2006) and are more critical in descent kinship regimes than in affinal kinship regimes (Nauck 2001). The partner choice concerns the whole family in descent kinship regimes, whereas it is an individual matter in affinal kinship regimes. More specifically, non-Western countries (e.g., Turkey) are often categorized as descent kinship regimes while Germany and other Western countries are categorized as affinal kinship regimes. Munniksma et al. (2012) study ethnic group differences in parental acceptance of their children's intimate out-group relations in the Netherlands and show that Dutch parents are more likely to accept their children's interethnic partner choice than Turkish and Moroccan parents are. The authors attribute it, among others, to hampering the intergenerational transmission of cultural values.

Given the differences in family functioning, it is essential to study the effect of family ties on interethnic partner choices separately for natives and migrants. For migrant families, and particularly for migrant parents, migration represents a discontinuity in the 
transmission process of values and norms (Berry 1992). Transmission processes from parents to their children (i.e., vertical/intergenerational transmission) compete with the transmission process among peers (i.e., horizontal transmission). Parents transfer culturespecific traits, values, and norms from the country of origin while peers are responsible for the transmission of values and norms of the host country. Horizontal and vertical transmission may stand in competition with one another. Thus, migrant parents may experience the transfer as more difficult but at the same time as more critical than native parents (Phalet/Schönpflug 2001). As a result, migrant parents intensify horizontal transmission to ensure that children internalize these values next to the ones from the host country.

Why and how do families affect the interethnic partner choice? Kalmijn (1998) proposes that group identification and group sanctions are the two underlying mechanisms. The first refers to a sense of belonging to a social group and solidarity towards that group. A strong sense of group identification has a detrimental effect on interethnic partner choice because individuals have internalized group norms of endogamy (see Hughes et al. 2006 for a review on racial and ethnic socialization mechanisms). The group identification itself depends on the diversity of the group's network; Kalmijn (1998) suggests that group identification and solidarity will be stronger if younger generations grow up in a homogenous network. The second mechanism suggests that individuals may still marry within their social group despite low levels of group identifications because they fear group sanctions. In the family context, sanctions refer to the withdrawal of support or advice (Hohmann-Marriott/Amato 2008). Research indicates that parents play a major role in their children's partner choices despite low parental control in most Western countries (Carol 2015). Van Zantvliet et al. (2014) point out that even though parental control decreases when children grow up, this does not concern partner preferences and choices. This explains why interethnic partnerships are rare if parental attitudes toward members from other cultural groups as close kin by marriage are negative.

Group identification and group sanctions indicate that the relation between parents and children, as well as the family in general, influence the partner choice in terms of the partner's cultural background (Huijnk/Liefbroer 2012; Huijnk et al. 2013). In this case, cohesive families are characterized by strong norms of family obligation and frequent contact with family members (Silverstein/Bengtson 1997). The family may exclude outgroup members to ensure cohesion. Therefore, family members may be less likely to accept a member of another ethnic group as close kin by marriage. The maintenance of cohesive ties may be particularly pronounced in migrant families, since otherwise, the transmission of culture-specific traits may be endangered. Chances of an interethnic partner choice may decrease as a result of cohesive family ties. I thus expect cohesive family relations, as indicated by contact frequency and proximity, to reduce the likelihood of being in an interethnic partnership for natives and migrants (Hypothesis 1).

In contrast to the closing nature of cohesive families, indicators of family warmth like emotional closeness and feelings of affection increase the acceptance of members from other ethnic groups as close kin by marriage (Huijnk et al. 2013). Similarly, strong and emotionally supportive family relations make families more tolerant towards out-group members as future family members (Glanville/Paxton 2007). This type of relationship increases levels of generalized trust (ibid.) that has been linked to more positive attitudes toward other ethnic groups (Huijnk/Liefbroer 2012). Given that positive attitudes toward 
other ethnic groups increase the chances of interethnic partner choices, I expect that affective family relations increase the likelihood of an interethnic partner choice for natives and migrants (Hypothesis 2).

The family structure determines relationships of family members (Silverstein/Giarrusso 2010; van der Pas et al. 2013) that in turn may affect the interethnic partner choice. In her study on parent-child contact in different family structures, Steinbach (2013) indicates that the diversification of familial structures reduces levels of family cohesion, both in native and migrant families; most contact prevails in families with both biological parents in a partnership compared to those parents who have a new partner or no partner. Huijnk et al. (2013) show that attitudes towards ethnic minorities as close kin by marriage are more favorable in bigger families. In the vein of intermarriages and stepfamilies, cohesive bonds are already weakened which may lead to openness towards other ethnic groups as kin by marriage. In that case, interethnic partnerships in traditional families are less likely than in structurally diverse families particularly among migrants (Hypothesis 3 ).

\section{Data, operationalization, and analytic strategy}

\section{Data}

To investigate how family relations are associated with the interethnic partner choice I draw on data from the German Family Panel (pairfam; Brüderl et al. 2016). Pairfam is a multidisciplinary longitudinal study in Germany. It gathers annual information on the development of people's way of living, their partnerships, parenthood, and intergenerational relationships. Participants born in one of the three cohorts 1991-1993, 1981-1983, and 1971-1973 were drawn randomly from all persons living in private households in Germany. The sample is proportional to the German population, and thus, the share of migrants is not larger than the share in the entire German population. The interview is conducted only in German. Persons with insufficient German language skills were not able to participate in the survey. In effect, the number of persons with a migration background is low. That is, in the first wave, around 13 percent of the original sample are migrants $(\mathrm{N}=1,637)$ whereas the share of migrants in Germany is about 20 percent. Despite the low number of migrants in pairfam, the main advantage of the data is the availability of rich data on partnerships and family relations. Other surveys like the Generations and Gender Survey draw an additional sample of migrants (Turkish subsample for Germany) but are limited to few objective questions on parent-child relations and have no detailed questions on intergenerational solidarity or sibling relationships.

For the analysis, I rely on data from wave five that was collected from 2012 to 2013. This wave introduces questions on the country of birth of the respondent's parents and the partner's parents. The initial sample consists of 7,245 respondents of which nine percent are migrants. The analytical sample includes respondents who are in a partnership $(\mathrm{N}=5,025)$ and of whom at least one parent is alive and in contact $(\mathrm{N}=4,743)$. To account for missing data, I use single stochastic regression imputation (Enders 2010: 46-49). In total, I analyze how family relations relate to interethnic partnerships for 3,873 natives and 870 migrants. 


\section{Operationalization}

The dependent variable of this study is interethnic partnership. Respondents are in an interethnic partnership if their cultural background is different from their partner's cultural background. I use the respondent's and parent's country of birth to identify the cultural background and migration status (i.e., native German, first-generation migrant, descendants of immigrants). I group respondents who are born in Germany and whose parents are born in Germany as native Germans. Those, who are born in another country than Germany and whose parents are not born in Germany are classified as first-generation migrants. Their cultural background is considered equal to their country of birth. Descendants of immigrants are respondents who are born in Germany but whose parents are not. In that case, their cultural background is considered similar to their parent's country of birth. The mother's country of birth is used to indicate the respondent's cultural background when parents are not born in the same country. However, the respondent's cultural background is considered equal to the father's country of birth if the mother is born in Germany and the father is not. Furthermore, I group countries with somewhat similar cultural backgrounds (e.g., countries from former Yugoslavia or the former Soviet Union) into one category.

Cohesive, affective and diverse family relations are the main predictors of interethnic partnerships in this study. Cohesive and affective ties refer respectively to the average relationship between respondents and their family members - i.e., mother, father, and siblings. I use contact frequency and proximity to family members to measure cohesive ties. Contact frequency is measured by the question "How often are you in contact with your [family member], adding up all visits, letters, phone calls, etc.?" and response categories range from daily to never on a seven-point scale. Proximity is measured by the timely distance to family members using the question "How much time do you need to get to your [family member]'s dwelling?" with response categories on a six-point scale ranging from "we live in the same house" to " 3 hours and more". The construct of emotional closeness measures affective relations with the question "How close do you feel to your [family member] today emotionally" on a 5-point scale ranging from not at all close to very close. Given the different range of response categories of these three constructs, I norm the variables so that values range from zero to one with higher values indicating stronger relations. Diverse family relations capture the family structure of respondents and are classified into (1) traditional family relations where respondent's parents are married and share a household, (2) stepfamily where the respondent has at least one stepparent, and thus, parents are not in a relationship, and at least one parent has a partner, and (3) separated family where respondent's parents are not in a relationship and neither of the parents has a new partner.

The control variables used in the analyses cover respondents sociodemographic characteristics (gender, age, and tertiary education), religious identification (no religion, Christian, Islam, other) and frequency of praying. I add a variable measuring the size of the area in that the respondent lives to control for opportunity structure of interethnic partner choices. Lastly, I include a dummy for the migrant generation (first generation migrant, descendants of immigrants) in the models for the interethnic partner choices of migrants. Table 1 shows the characteristics of the sample differentiated by migrant status. 
Table 1: Sample characteristics

\begin{tabular}{|c|c|c|c|c|c|c|}
\hline & \multicolumn{2}{|c|}{ Natives } & \multicolumn{2}{|c|}{ Migrants } & \multirow[b]{2}{*}{$\min$} & \multirow[b]{2}{*}{$\max$} \\
\hline & Mean & SD & Mean & SD & & \\
\hline Interethnic union & 0.13 & 0.34 & 0.60 & 0.49 & 0 & 1 \\
\hline Contact & 0.72 & 0.18 & 0.72 & 0.17 & 0 & 1 \\
\hline Proximity & 0.53 & 0.24 & 0.46 & 0.26 & 0 & 1 \\
\hline Affection & 0.72 & 0.17 & 0.74 & 0.17 & 0 & 1 \\
\hline Married parents & 0.60 & 0.49 & 0.63 & 0.48 & 0 & 1 \\
\hline Parent with partner & 0.26 & 0.44 & 0.18 & 0.38 & 0 & 1 \\
\hline Parent no partner & 0.15 & 0.35 & 0.20 & 0.40 & 0 & 1 \\
\hline Age & 31.65 & 7.94 & 32.15 & 7.87 & 0 & 42 \\
\hline Female & 0.56 & 0.50 & 0.61 & 0.49 & 0 & 1 \\
\hline High education & 0.29 & 0.45 & 0.31 & 0.46 & 0 & 1 \\
\hline No religion & 0.40 & 0.49 & 0.26 & 0.44 & 0 & 1 \\
\hline Christian & 0.59 & 0.49 & 0.49 & 0.50 & 0 & 1 \\
\hline Islam & 0.00 & 0.05 & 0.16 & 0.36 & 0 & 1 \\
\hline Other religion & 0.01 & 0.11 & 0.10 & 0.30 & 0 & 1 \\
\hline Frequency praying & 5.06 & 1.07 & 4.72 & 1.36 & 0 & 6 \\
\hline Size municipality & 3.91 & 1.67 & 4.54 & 1.70 & 1 & 7 \\
\hline Native born & 1.00 & 0.00 & 0.00 & 0.00 & 0 & 1 \\
\hline 1st gen. migrant & & & 0.51 & 0.50 & 0 & 1 \\
\hline Migrant descendants & & & 0.49 & 0.50 & 0 & 1 \\
\hline
\end{tabular}

\section{Analytic Strategy}

Logistic regression models are run to answer whether and how cohesive, affective and diverse family relations are linked to the interethnic partner choice because the dependent variable is dichotomous - coethnic versus an interethnic partnership. In total, I run three separate models: (1) native Germans having a partner with a migration origin in comparison to being in a partnership with another native German, (2) migrants having a native German partner in contrast to having a partner with the same cultural origin as themselves, and (3) migrants having a migrant partner but from a different migrant group than themselves compared to having a partner from the same migrant group.

Given that in logistic regression models, the logits or odds ratios are non-additive, non-comparable and challenging to interpret intuitively, average marginal effects (AME) are shown instead. AMEs refer to the average effect on the probability of observing the outcome variable holding all other values constant. That is, AMEs indicate by how many percentage points the effect of an independent variable $\mathrm{x}$ on the dependent variable changes if $x$ increases by one unit. The advantage of AMEs is that it is possible to interpret the strength of the effect and to compare it between models.

\section{Results}

Before delving into how family ties are linked to the interethnic partner choice, I first explore with whom natives and migrants are in a partnership. Table 2 demonstrates the share of coethnic and interethnic partnerships. A high percentage of native Germans is in a partnership with another native German whereas only 13 percent are in an interethnic partnership. This pattern is different for some migrants where the share of interethnic 
partnerships is higher than the share of coethnic partnerships such as for migrants from Poland. For migrants from Turkey and the former Soviet Union, the share of coethnic unions is higher than the share of interethnic unions. For all migrant groups, the share of partnerships with another migrant group is the lowest.

Table 2: Share and type of interethnic partnerships (in \%)

\begin{tabular}{|c|c|c|c|c|c|c|}
\hline & \multicolumn{2}{|c|}{$\begin{array}{c}\text { Natives } \\
(\mathbf{N}=\mathbf{3}, \mathbf{8 7 3})\end{array}$} & \multicolumn{4}{|c|}{$\begin{array}{c}\text { Migrants } \\
(\mathbf{N}=\mathbf{8 7 0})\end{array}$} \\
\hline & 1 & 2 & 1 & 2 & 3 & $\mathbf{N}$ \\
\hline German & 87.40 & & & & & \\
\hline Turkey & & 0.67 & 74.58 & 16.95 & 8.47 & 118 \\
\hline Repatriates & & 1.06 & 65.24 & 25.67 & 9.09 & 187 \\
\hline Poland & & 3.18 & 22.36 & 65.22 & 12.42 & 161 \\
\hline Southern Europe & & 0.85 & 17.14 & 62.86 & 20.00 & 35 \\
\hline (South) Eastern Europe & & 1.37 & 26.75 & 54.14 & 19.11 & 157 \\
\hline North, West, Central Europe & & 0.83 & 10.47 & 68.60 & 20.93 & 86 \\
\hline Middle East, Hindu Kush & & 0.18 & 47.62 & 30.95 & 21.43 & 42 \\
\hline Asia & & 0.34 & 39.29 & 50.00 & 10.71 & 28 \\
\hline North America & & 0.23 & 0.00 & 69.23 & 30.77 & 13 \\
\hline Central and South America & & 0.39 & 20.00 & 55.00 & 25.00 & 20 \\
\hline Africa & & 0.44 & 40.91 & 40.91 & 18.18 & 22 \\
\hline Other & & 3.07 & 0.00 & 0.00 & 100.00 & 1 \\
\hline
\end{tabular}

Note: $(1)=$ coethnic partnership between natives; $(2)=$ interethnic partnership between native and migrant; (3) interethnic partnership between migrants

Turning to multivariate results, Table 3 displays the AMEs of the logistic regression models for the interethnic partner choices of natives and migrants.

According to the first hypothesis, cohesive family relations reduce the odds of being in an interethnic partnership. The results partly support the hypothesis. For natives, living close to family members and frequent contact with family members has no significant effect on being in an interethnic partnership. For migrants, however, frequent contact with family members reduces the likelihood of having a native German partner by 32 percentage points and by 35 percentage points for having a partner from another migrant group. In turn, living close to family members has no significant effect for migrants.

The second hypothesis postulates that affective family relations increase the likelihood of being in an interethnic partnership. For both natives and migrants, the effect of emotional closeness does not relate significantly to being in an interethnic partnership. Other measures of affective family relations like intimacy did not yield significant effects for migrants and natives (not shown). 
Table 3: Models for interethnic partner choice of natives and migrants

\begin{tabular}{|c|c|c|c|}
\hline & \multirow{2}{*}{$\begin{array}{c}\text { Natives } \\
\text { AME }\end{array}$} & \multicolumn{2}{|c|}{ Migrants } \\
\hline & & $\begin{array}{c}\text { Native partner } \\
\text { AME }\end{array}$ & $\begin{array}{c}\text { Other migrant partner } \\
\text { AME }\end{array}$ \\
\hline Contact & $\begin{array}{c}0.050 \\
(1.05)\end{array}$ & $\begin{array}{l}-0.319 * \\
(-2.45)\end{array}$ & $\begin{array}{l}-0.353^{*} \\
(-2.15)\end{array}$ \\
\hline Proximity & $\begin{array}{l}-0.052 \\
(-1.72)\end{array}$ & $\begin{array}{l}0.046 \\
(0.59)\end{array}$ & $\begin{array}{l}0.052 \\
(0.56)\end{array}$ \\
\hline Affection & $\begin{array}{l}-0.048 \\
(-1.18)\end{array}$ & $\begin{array}{l}0.042 \\
(0.40)\end{array}$ & $\begin{array}{l}0.038 \\
(0.28)\end{array}$ \\
\hline \multicolumn{4}{|c|}{ Diversity (ref. parents married) } \\
\hline Parent with partner & $\begin{array}{l}0.031 * \\
(2.24)\end{array}$ & $\begin{array}{l}-0.0025^{*} \\
(-0.58)\end{array}$ & $\begin{array}{l}0.051 \\
(0.96)\end{array}$ \\
\hline Parent no partner & $\begin{array}{l}0.051 * * \\
(2.92)\end{array}$ & $\begin{array}{c}0.004 \\
(0.11)\end{array}$ & $\begin{array}{c}0.012 \\
(0.23)\end{array}$ \\
\hline Age & $\begin{array}{l}-0.001 \\
(-1.05)\end{array}$ & $\begin{array}{l}-0.004 \\
(-1.65)\end{array}$ & $\begin{array}{l}-0.009)^{* *} \\
(-3.00)\end{array}$ \\
\hline Female & $\begin{array}{l}-0.005 \\
(-0.42)\end{array}$ & $\begin{array}{c}0.039 \\
(1.29)\end{array}$ & $\begin{array}{l}-0.029 \\
(-0.77)\end{array}$ \\
\hline High education & $\begin{array}{r}0.017 \\
(1.33)\end{array}$ & $\begin{array}{l}0.089 \\
(2.56)\end{array}$ & $\begin{array}{c}0.066 \\
(1.53)\end{array}$ \\
\hline \multicolumn{4}{|l|}{ Religion (ref. no religion) } \\
\hline Christian & $\begin{array}{l}0.052 \text { *** } \\
(4.27)\end{array}$ & $\begin{array}{l}-0.022 \\
(-0.53)\end{array}$ & $\begin{array}{l}0.034 \\
(0.62)\end{array}$ \\
\hline Muslim & . & $\begin{array}{l}-0.493 * * * \\
(-9.87)\end{array}$ & $\begin{array}{l}-0.200 * * * \\
(-3.61)\end{array}$ \\
\hline Other religion & $\begin{array}{l}0.018 \\
(0.37)\end{array}$ & $\begin{array}{l}-0.204^{* *} \\
(-3.09)\end{array}$ & $\begin{array}{l}0.002 \\
(0.04)\end{array}$ \\
\hline Frequency praying & $\begin{array}{l}0.005 \\
(0.79)\end{array}$ & $\begin{array}{l}0.008 \\
(0.66)\end{array}$ & $\begin{array}{l}0.020 \\
(1.38)\end{array}$ \\
\hline Size municipality & $\begin{array}{l}0.009 * * \\
(2.73)\end{array}$ & $\begin{array}{l}-0.022^{*} \\
(-2.50)\end{array}$ & $\begin{array}{l}0.000 \\
(0.02)\end{array}$ \\
\hline Migrant descendants & & $\begin{array}{l}0.410)^{* * *} \\
(13.16)\end{array}$ & $\begin{array}{l}0.329 * * * \\
(7.11)\end{array}$ \\
\hline $\mathrm{N}$ & 3873 & 742 & 475 \\
\hline
\end{tabular}

Average Marginal Effects (AME) are shown; t statistics in parentheses;

$* \mathrm{p}<0.05, * * \mathrm{p}<0.01, * * * \mathrm{p}<0.001$

The data partly support the third hypothesis, which suggests that in traditional families, interethnic partnerships are less likely than in structurally diverse families. Natives are relatively more likely to have a migrant partner if parents are not married. The effect is by three percentage points larger for respondents whose parents are divorced and are in a new partnership and by five percentage points larger for natives whose parents are divorced but not married. However, the effect is not significant for migrants.

\section{Discussion}

While previous research has mainly focused on parental characteristics and their attitudes for explaining interethnic partnerships, this study highlights the role of family relations. Similar to group characteristics that lead to the acceptance of ethnically different neighbors or classmates, family functioning and family ties determine the attitudes of accepting 
ethnic minorities as close kin by marriage (Huijnk et al. 2013). In response to the initial research question of how family relations influence the interethnic partner choice, I find that strong in-group ties relate to a coethnic rather than interethnic partner choice for migrants and not for natives. In migrant families, cohesive ties to family members relate significantly to interethnic partner choices. This finding underlines the fact that migrant parents may experience difficulties in transmitting culture-specific norms and values to their children and thus, oppose interethnic unions.

More specifically, the findings confirm that one form of structural family cohesion the contact frequency - inhibits the interethnic partner choice of migrants. This finding is consistent with prior research on the role of family relations for attitudes toward members of other ethnic groups as close kin by marriage (Huijnk et al. 2010). That is, cohesive ties are expressed via frequent contact with family members for migrants. Migrants that are in regular contact with family members are relatively less likely to have a native partner or a partner from a different migrant group. This finding suggests that the person's network may consist of family members and may confirm that growing up and being in a homogenous network enhances group identification (Kalmijn 1998). Furthermore, interethnic partnerships are relatively more likely in native families with structurally diverse relations than in native families with traditional relations. However, this is not the case in migrant families. That is, for natives, choosing a partner with a migrant background is more likely, if parents are not married and living together. Moreover, affective family relations do not relate significantly to the interethnic partner choice for both natives and migrants. This finding contradicts previous findings that propose that emotionally supportive families tolerate out-group members. This finding is also in contrast to other studies that find a positive influence of warm family relations on attitudes toward interethnic partnerships. Huijnk et al. (2013) point out that attitudes toward interethnic partnerships are more favorable in families with affective ties because members of these families have higher levels of generalized trust. My findings, however, show that emotional family ties do not promote interethnic partner choices, neither in native nor in migrant families.

While the current study is the first to address the question of how family relations relate to interethnic partnerships using a large-scale data set with a broad range of family relationship indicators, it also has some limitations. This study uses a cross-sectional design and hence, does not capture family relations before or at the beginning of the partnership as well as how these relations develop over time. On the one hand, this may not pose a problem since family relations remain to a certain degree constant over time. On the other hand, reversed causality may play a role: family relations may have deteriorated because of the interethnic partner choice. Longitudinal research that would be able to follow individuals in their partner choice and capture the changes in family relations is necessary. Next, as previous research has pointed out ethnic groups differ depending on a broad variety of characteristics. For example, partnerships with migrants who have the same religious background as natives are more common than interreligious partnerships (Dribe/Lundh 2011; van Zantvliet et al. 2014). Ethnic groups also vary in how they evaluate interethnic partnerships (Munniksma et al. 2012; Carol 2013a). In turn, this is closely linked to the ethnic hierarchy in partner choice (e.g., Lin/Lundquist 2013) and to the different kinship regimes (Nauck/Suckow 2006). The findings hint towards the importance of religion in interethnic partner choices - that is, Muslim migrants are less likely to be in 
an interethnic partnership compared to migrants with no religious affiliation. However, more differentiated analyzes would lack statistical power because of small sample sizes. In particular, a more nuanced differentiation of family relations from affinal and descent kinship regimes may provide more clarity about the role of the family in interethnic partner choices. Given that particularly Turkish migrants are underrepresented in the sample, the strength of the effect of family relations may be underestimated. In this sense, generalizing these findings to the general German population is not possible because the migrant sample is not representative of the German migrant population. Nevertheless, this study offers first insights into the role of family ties in interethnic partner choices.

Despite those limitations, interethnic partnerships depend on family functioning and family ties. For future work, it is interesting to disentangle family relations in greater detail. That is, does the relationship to all family members affect interethnic partner choice similarly? Especially the role of lateral ties and relationships with distant relatives may yield different results for native and migrants. Studying migrant-group specific differences in family functioning and interethnic partner choice is also necessary. Highlighting the role of family ties may shed more light on why migrant groups differ in their likelihood to have a native partner. More specifically, are migrants less likely to intermarry because of close ties to their family?

Overall, this study confirms that family relations are not only associated with attitudes toward interethnic partnerships but also with actual partner choices for migrants. Thus, not just individual preferences and the opportunity structure foster or hinder interethnic partner choices but also third parties. While religious differences between natives and some migrants groups are often a prominent explanation for why some migrant groups are more likely to intermarry than others, my findings show that family relationships are also important for interethnic partner choices.

\section{References}

Berry, J. W. (1992). Acculturation and adaptation in a new society. International Migration, 30, pp. 6985. doi:10.1111/j.1468-2435.1992.tb00776.x.

Brüderl, J., Hank, K., Huinink, J., Nauck et al. (2016). The German Family Panel (pairfam). GESIS Data Archive, Cologne. ZA5678 Data file Version 7.0.0. doi:10.4232/pairfam.5678.7.0.0.

Carol, S. (2013a). Intermarriage attitudes among minority and majority groups in Western Europe. The role of attachment to the religious in-group. International Migration, 51, 3, pp. 67-83. doi:10.1111/imig. 12090 .

Carol, S. (2013b). The intergenerational transmission of intermarriage attitudes and intergroup friendships. The role of Turkish migrant parents. Journal of Ethnic and Migration Studies, 40, 10, pp. 1550-1571. doi:10.1080/1369183X.2013.872557.

Carol, S. (2015). Like will to like? Partner choice among Muslim migrants and natives in Western Europe. Journal of Ethnic and Migration Studies, 42, 2, pp. 261-276. doi:10.1080/1369183X.2014.963037.

Dribe, M. \& Lundh, C. (2011). Cultural dissimilarity and intermarriage. A longitudinal study of immigrants in Sweden 1990-2051. International Migration Review, 45, 2, pp. 297-324. doi:10.1111/j.1747-7379.2011.00849.x.

Enders, C. K. (2010). Applied missing data analysis. New York: Guilford Press (Methodology in the social sciences). 
Glanville, J. L. \& Paxton, P. (2007). How do we learn to trust? A confirmatory tetrad analysis of the sources of generalized trust. Social Psychology Quarterly, 70, 3, pp. 230-242. doi:10.1177/019027250707000303.

Gordon, M. (1964). Assimilation in American life: The role of race, religion and national origins. New York: Oxford University Press.

Hohmann-Marriott, B. E. \& Amato, P. (2008). Relationship quality in interethnic marriages and cohabitations. Social Forces, 87, 2, pp. 825-855. doi:10.1353/sof.0.0151.

Hughes, D., Rodriguez, J., Smith, E. P. et al. (2006). Parents' ethnic-racial socialization practices: a review of research and directions for future study. Developmental Psychology, 42, 5, pp. 747-770. doi:10.1037/0012-1649.42.5.747.

Huijnk, W. \& Liefbroer, A. C. (2012). Family influences on intermarriage attitudes. A sibling analysis in the Netherlands. Journal of Marriage and Family, 74, 1, pp. 70-85. doi:10.1111/j.1741-3737.2011.00882.x.

Huijnk, W., Verkuyten, M. \& Coenders, M. (2010). Intermarriage attitude among ethnic minority and majority groups in the Netherlands: The role of family relations and immigrant characteristics. Journal of Comparative Family Studies, 41, 3, pp. 389-414.

Huijnk, W., Verkuyten, M. \& Coenders, M. (2013). Family relations and the attitude towards ethnic minorities as close kin by marriage. Ethnic and Racial Studies, 36, 11, pp. 1890-1909. doi:10.1080/01419870.2012.699086.

Kalmijn, M. (1998). Intermarriage and homogamy: causes, patterns, trends. Annual Review of Sociology, 24, pp. 395-421. doi:10.1146/annurev.soc24.1.395.

Kalmijn, M. \& van Tubergen, F. (2006). Ethnic intermarriage in the Netherlands. Confirmations and refutations of accepted insights. European Journal of Population / Revue Européenne de Démographie, 22, 4, pp. 371-397. doi:10.1007/s10680-006-9105-3.

Lichter, D. T., Qian, Z. \& Tumin, D. (2007). Whom do immigrants marry? Emerging patterns of intermarriage and integration in the United States. The ANNALS of the American Academy of Political and Social Science, 662, 1, pp. 57-78. doi:10.1177/0002716215594614.

Lin, K.-H. \& Lundquist, J. (2013). Mate selection in cyberspace. The intersection of race, gender, and education. American Journal of Sociology, 119, 1, pp. 183-215. doi:10.1086/673129.

Munniksma, A., Flache, A., Verkuyten, M. \& Veenstra, R. (2012). Parental acceptance of children's intimate ethnic outgroup relations. The role of culture, status, and family reputation. International Journal of Intercultural Relations, 36, 4, pp. 575-585. doi:10.1016/j.ijintrel.2011.12.012.

Nauck, B. (2001). Generationenbeziehungen und Heiratsregimes - theoretische Überlegungen zur Struktur von Heiratsmärkten und Partnerwahlprozessen am Beispiel der Türkei und Deutschland. In: Klein, T. (Hrsg.), Partnerwahl und Heiratsmuster. Wiesbaden: VS Verlag für Sozialwissenschaften, pp. 35-55. doi:10.1007/978-3-663-11009-5_2.

Nauck, B. \& Suckow, J. (2006). Intergenerational relationships in cross-cultural comparison. Journal of Family Issues, 27, 8, pp. 1159-1185. doi:10.1177/0192513X06288125.

Phalet, K. \& Schönpflug, U. (2001). Intergenerational transmission of collectivism and achievement values in two acculturation contexts: The case of Turkish families in Germany and Turkish and Moroccan families in the Netherlands. Journal of Cross-Cultural Psychology, 32, 2, pp. 186-201. doi:10.1177/0022022101032002006.

Qian, Z. \& Lichter, D. T. (2001). Measuring marital assimilation. Intermarriage among natives and immigrants. Social Science Re-search, 30, 2, pp. 289-312. doi:10.1006/ssre.2000.0699.

Schroedter, J. (2013). Ehemuster von Migranten in Westdeutschland. Analysen zur sozialen Integration auf Basis des Mikrozensus. Wiesbaden: Springer VS.

Silverstein, M. \& Bengtson, V. L. (1997). Intergenerational solidarity and the structure of adult childparent relationships in American families. American Journal of Sociology, 103, 2, pp. 429-460. doi:10.1086/231213.

Silverstein, M. \& Giarrusso, R. (2010). Aging and family life: A decade review. Journal of Marriage and Family, 72, 5, pp. 1039-1058. doi:10.1111/j.1741-3737.2010.00749.x. 
Song, M. (2009). Is intermarriage a good indicator of integration? Journal of Ethnic and Migration Studies, 35, 2, pp. 331-348. doi:10.1080/13691830802586476.

Statistisches Bundesamt (2017). Bevölkerung und Erwerbstätigkeit: Bevölkerung mit Migrationshintergrund - Ergebnisse des Mikrozensus 2016. Wiesbaden: Statistisches Bundesamt (Destatis) (Fachserie 1, Reihe 2.2).

Steinbach, A. (2013). Family structure and parent-child contact. A comparison of native and migrant families. Journal of Marriage and Family, 75, 5, pp. 1114-1129. doi:10.1111/jomf.12060.

Steinbach, A. \& Hank, K. (2016). Familiale Generationenbeziehungen aus bevölkerungssoziologischer Perspektive. In: Niephaus, Y., Kreyenfeld, M. \& Sackmann, R. (Hrsg.), Handbuch Bevölkerungssoziologie. Wiesbaden: Springer VS (Springer Nachschlage Wissen), pp. 367-391.

van der Pas, S., van Tilburg, T. G. \& Silverstein, M. (2013). Stepfamilies in later life. Journal of Marriage and Family, 75, 5, pp. 1065-1069. doi:10.1111/jomf.12054.

van Zantvliet, P. I., Kalmijn, M. \& Verbakel, E. (2014). Early partner choices of immigrants. The effect of preferences, opportunities and parents on dating a native. Journal of Ethnic and Migration Studies, 41, 5, pp. 772-794. doi:10.1080/1369183X.2014.948391.

Submitted on/Eingereicht am: 20.12.2016

Accepted on/Angenommen am 20.09.2018

Address of the author/Anschrift der Autorin;

Olga Grünwald, M.Sc.

Netherlands Interdisplinary Demographic Institute (NIDI)

P. O. Box 11650

2502 AR The Hague

The Netherlands/Niederlande

E-Mail/Email: grunwald@nidi.nl 